\title{
DRIFTS-MS-SSITKA Study of the Reverse Water-Gas Shift Reaction
}

\author{
F.C. Meunier ${ }^{1 *}$, D. Tibiletti ${ }^{1}$, A. Goguet ${ }^{1}$ and R. Burch ${ }^{1}$ \\ 1 CenTACat, School of Chemistry and Chemical engineering, \\ Queen's University Belfast, Belfast, BT9 5AG, Northern Ireland - United Kingdom \\ e-mail: f.meunier@qub.ac.uk -d.tibiletti@qub.ac.uk-a.goguet@qub.ac.uk - r.burch@qub.ac.uk \\ ${ }^{*}$ Corresponding author
}

Résumé - Étude de la réaction retour du gaz à l'eau par DRIFT-MS-SSITKA - Une méthode operando pour l'étude des mécanismes de réaction en catalyse hétérogène a été développée par l'utilisation du réacteur de la cellule infra rouge en mode de réflexion diffuse et une méthode échange isotopique à l'état stationnaire (SSITKA). Cette méthode permet l'étude simultanée de l'échange isotopique des espèces adsorbées en surface (par DRIFTS) et celle du produit de la réaction (par spectrométrie de masse). Cet article décrit nos premiers travaux en ce domaine concernant la réaction en retour du gaz à l'eau (WGS, $\mathrm{CO}_{2}+\mathrm{H}_{2} \rightarrow \mathrm{CO}+\mathrm{H}_{2} \mathrm{O}$ ), en soulignant le besoin d'utiliser des méthodes stationnaires pour que la réactivité réelle des espèces de surface puisse être déterminée.

Abstract - DRIFTS-MS-SSITKA Study of the Reverse Water-Gas Shift Reaction - An operando method for the analysis of heterogeneous catalytic reaction was developed using the reactor of a diffuse reflectance FTIR in situ cell and a steady-state isotopic kinetic transient (SSITKA) technique. This method allowed following simultaneously the isotopic exchange of the adsorbates present at the catalyst surface (by DRIFTS) and that of the reaction product (by mass spectrometry). This paper reviews an early example of our studies on the reverse water-gas-shift (WGS, $\mathrm{CO}_{2}+\mathrm{H}_{2} \rightarrow \mathrm{CO}+\mathrm{H}_{2} \mathrm{O}$ ), also re-emphasising the need to use steady-state conditions if the true operando reactivity of the adsorbates is to be determined. 


\section{INTRODUCTION}

Operando and in situ investigations of heterogeneous catalytic reactions are receiving increasing attention, allowing the simultaneous collection of spectroscopic and kinetic data under conditions relevant to actual catalytic processes [1-7] A number of techniques are nowadays routinely combined, yet it is surprising that the simultaneous utilisation of steadystate isotopic transient kinetic analysis (SSITKA) and spectroscopy is still rare. Tamaru and co-workers were the first to report on the combined utilisation of spectroscopic data during SSITKA analysis (so-called isotopic "jump" method) [8]. However, Ueno et al. were using a cell with a double bed, i.e. one thin wafer was used for the transmission IR measurement, while a much larger neighbouring bed was used to achieve a measurable conversion of the reactant within the cell. Later, Chuang et al. [9] applied the SSITKA technique for the simultaneous analysis of reactor effluent and of adsorbed species by in situ transmission FTIR spectroscopy using a single bed (i.e. a thin catalyst wafer). Since, most other SSITKA investigations have only been concerned with the analysis of the gas phase reactor effluent, which by itself provides already a number a valuable insights into reaction mechanisms [10-13]. Recently, Goguet et al. [14] and Jacobs and Davis [15] have reported a combined analysis of the exchange of the species both at the surface of the catalyst and in the gas phase during SSITKA investigation relating to the water-gas-shift (WGS, Equation 1) reaction.

$$
\mathrm{CO}+\mathrm{H}_{2} \mathrm{O} \leftrightarrow \mathrm{CO}_{2}+\mathrm{H}_{2}
$$

These authors used the combination of SSITKA and in situ IR to try to unravel the complex reaction pathway of the WGS reaction over noble metal supported on ceria, which are promising catalysts for the low temperature WGS needed for the production CO-free hydrogen. Various reaction mechanisms have been proposed regarding this reaction, some of which involved surface formate and/or carbonate species [16-20]. However, the conclusions of many of the IR studies were partly based on the observation of the surface species typically obtained under WGS reaction conditions and the decomposition/reactivity of these species in vacuum or atypical feed gases. Our laboratory has recently shown that the reactivity of carbonates and other surface species formed over $\mathrm{Pt} / \mathrm{CeO}_{2}$ during the reverse WGS (RWGS) reaction was strongly dependent on the experimental procedure used [21-22], and the data reported here summarise this earlier work. Other data showing how spectator species can be determined is also presented [14].

\section{EXPERIMENTAL}

The catalyst used in this study was a $2 \% \mathrm{Pt} / \mathrm{CeO}_{2}$ provided by Johnson Matthey. The specific surface area, measured by the BET method on a Micromeretics ASAP 2010, was $180 \mathrm{~m}^{2} \mathrm{~g}^{-1}$. The Pt dispersion, measured by $\mathrm{H}_{2}$ chemisorption on a Micromeretics Autochem 2910 at $193 \mathrm{~K}$ to minimize potential spillover of $\mathrm{H}_{2}$ onto the support [23], was $17 \%$. The purity of the gases used (i.e., $\mathrm{H}_{2}, \mathrm{He}, \mathrm{CO}_{2}, \mathrm{Ar}$, supplied by BOC) was higher than $99.95 \%$. The ${ }^{13} \mathrm{CO}_{2}$ was $99 \%$ pure (supplied by Cambridge Isotope Laboratories Inc). Unless otherwise stated, the reaction mixture was $1 \%{ }^{12} \mathrm{CO}_{2}+4 \% \mathrm{H}_{2}$ in $\mathrm{Ar}$, fed at a total flow rate of $100 \mathrm{~mL} \mathrm{~min}^{-1}$.

The experimental set-up consisted of an in situ high temperature diffuse reflectance IR cell (from Spectra-Tech ${ }^{\circledR}$ ) fitted with $\mathrm{ZnSe}$ windows and connected to the feed gas cylinders through low volume stainless-steel lines (Fig. 1). The gas flows were controlled by Aera mass flow controllers, which were regularly calibrated. A 4-way valve was used to allow a fast switching between two reaction feeds, when appropriate. The DRIFTS cell was located in a Bruker Equinox 55 spectrometer, operating at a resolution of $4 \mathrm{~cm}^{-1}$.

The wavenumber limits that were used for the quantification of the concentrations of the ${ }^{12} \mathrm{C}$-containing surface species of interest were as follows (the area of a given band was measured with the OPUS software, using a single-point baseline), all values being in $\mathrm{cm}^{-1}$ :

- formate: 2954-2944 (single-point baseline at 3050);

- carbonyl: 2110-2050 (single-point baseline at 2150);

- carbonate: 900-865 (single-point baseline at 795).

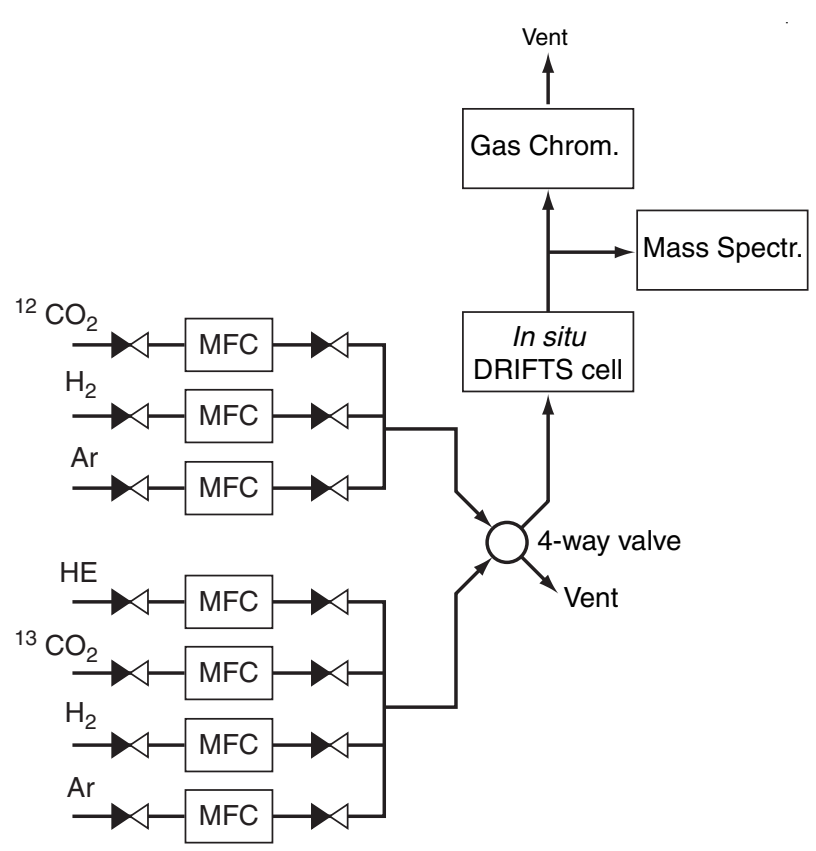

Figure 1

Schematic representation of the experimental setup used for the combined DRIFT-MS-SSITKA analysis. (MFC = mass flow controller). Pressure transducers were also used to allow accurately balancing the pressure drops in the system. 
The validity of the integration method (which only uses a narrow section of the various IR bands) was dealt in details in a previous paper [22].

\section{RESULTS}

The typical in situ DRIFT spectra obtained over the $2 \%$ $\mathrm{Pt} / \mathrm{CeO}_{2}$ under reverse WGS reaction feed is shown in Figure 2a. The assignment of the DRIFTS band has already been described in details elsewhere [14, 21]. Briefly, the bands in the region $3800-3300 \mathrm{~cm}^{-1}$ are related to ceria hydroxyl groups. The bands around $2800 \mathrm{~cm}^{-1}$ are associated with a bidentate formate species located on the ceria. The bands in the region $1800-1200 \mathrm{~cm}^{-1}$ were mostly due to the stretching vibration modes (symmetric and anti-symmetric) of the O-C-O group of free carboxylate, formate and carbonate species. Due to the complexity of this band structure, the deconvolution and interpretation of this region was not attempted. The complex band structure between 2100 and $1800 \mathrm{~cm}^{-1}$ is related to Pt-bound carbonyl species. The highfrequency side of the band (centred around $2070 \mathrm{~cm}^{-1}$ ) is associated with linearly bound $\mathrm{CO}$, probably on a distribution of heterogeneous adsorption sites, whereas the lower frequency side of the band may be related to bridged carbonyl species [24]. The bands in the $900-800 \mathrm{~cm}^{-1}$ region are associated with the out-of-plane vibration of carbonates species. While it is possible that some formates and carbonates may also be located on the metal, it is likely that the corresponding IR bands were swamped by that of the corresponding species located over the high surface area support.

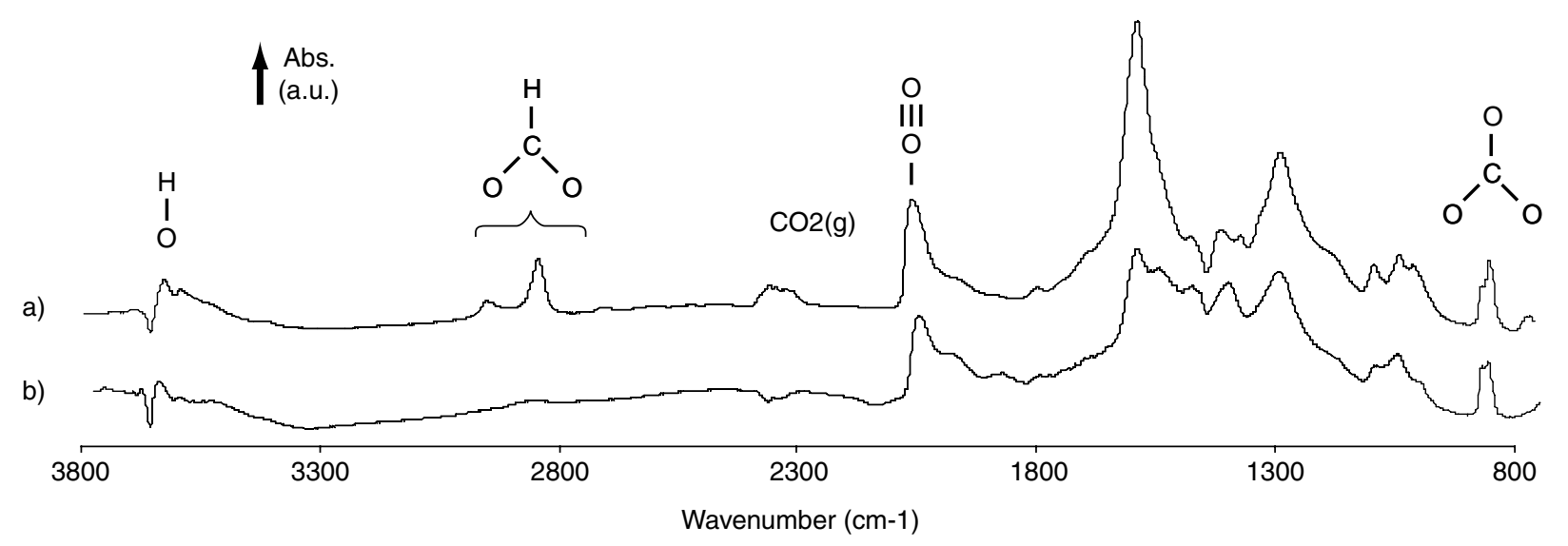

Figure 2.

a) Typical in situ DRIFT spectra obtained over of a $2 \% \mathrm{Pt} / \mathrm{CeO}_{2}$ at steady-state conditions under a RWGS feed: $1 \% \mathrm{CO}_{2}+4 \% \mathrm{H}_{2}$ in $\mathrm{Ar}$ at $498 \mathrm{~K}$. b) Corresponding in situ DRIFT spectrum obtained after 60 minutes under Ar at the same temperature. In both cases, the absorbance respective to the fresh material at the same temperature under Ar is reported.

a)

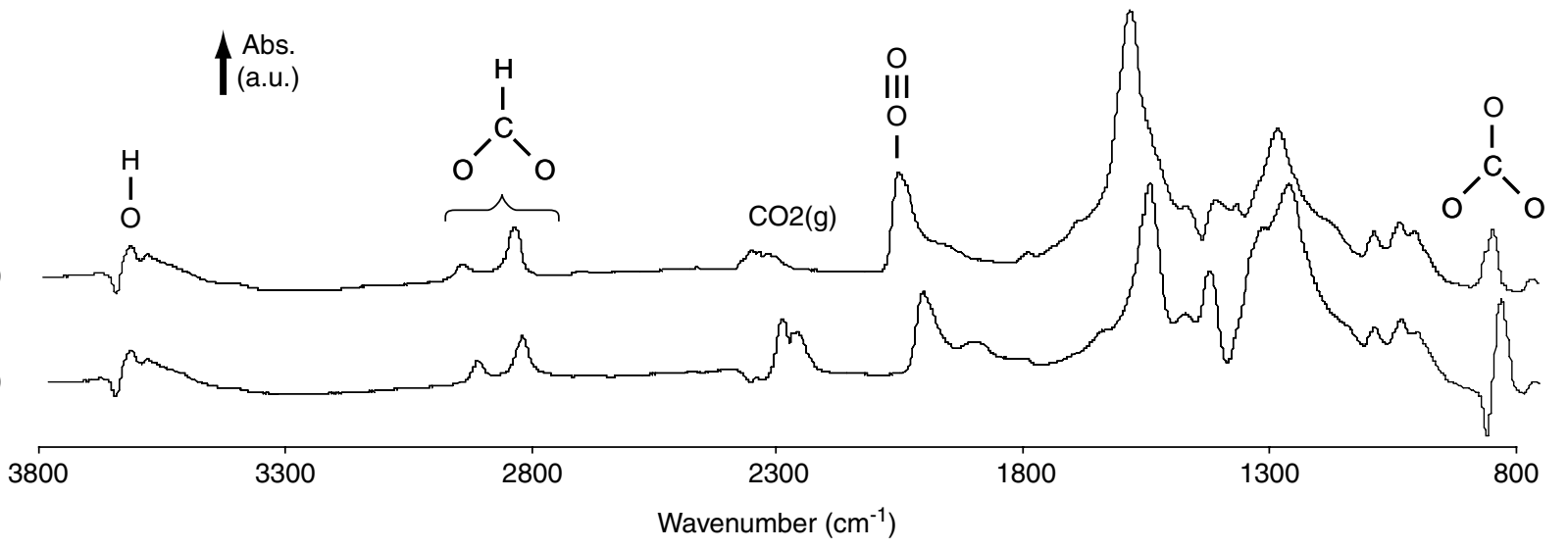

Figure 3

a) Typical in situ DRIFT spectra obtained over of a $2 \% \mathrm{Pt} / \mathrm{CeO}_{2}$ at steady-state conditions under a RWGS feed: $1 \%{ }^{12} \mathrm{CO}_{2}+4 \% \mathrm{H}_{2}$ in $\mathrm{Ar}$ at $498 \mathrm{~K}$. b) Corresponding in situ DRIFT spectrum obtained after 30 minutes under a labelled feed $\left(1 \%{ }^{13} \mathrm{CO}_{2}+4 \% \mathrm{H}_{2}\right.$ in $\left.\mathrm{Ar}\right)$ at the same temperature. In both cases, the absorbance respective to the fresh material at the same temperature under $\mathrm{Ar}$ is reported. 
After 60 min following a switch to a stream only containing $\operatorname{Ar}$ (Fig. 2b), the intensity of the formate band had essentially decreased to zero, while the carbonyl signal only decreased to a finite fraction of the initial intensity. Interestingly, the intensity of the carbonate bands remained mostly constant.

Figures $3 \mathrm{a}$ and $3 \mathrm{~b}$ show the spectra obtained under steadystate condition of RWGS feed, under a ${ }^{12} \mathrm{C}$-containing feed (Fig. 3a) and the corresponding ${ }^{13} \mathrm{C}$-containing feed (Fig. 3b). The structure of the spectra is essentially identical, except that the bands are shifted to a lower wavenumber (i.e. red-shifted) in the case of the ${ }^{13} \mathrm{C}$-containing species, due to the heavier mass of this isotope.

The quantitative analysis of the decrease of the intensity of the bands of the ${ }^{12} \mathrm{C}$-containing surface species during the purge under Ar and during the isotope exchange is reported in Figures $4 \mathrm{a}$ and $4 \mathrm{~b}$, respectively. Under Ar (Fig. 4a), the formates were the most reactive species, while carbonates were essentially non-reactive under these conditions. When switching to the labelled feed (Fig. 4b), a complete exchange of both the carbonyl and carbonate species could be obtained in less than $10 \mathrm{~min}$, that is, faster than the exchange time of the formates. It is also worth noting that the rate of isotopic exchange of the formates was slower than that of desorption/decomposition of these same species under Ar (i.e., time for $50 \%$ exchange and desorption/decomposition: 20 and $10 \mathrm{~min}$, respectively). These data clearly re-emphasise the fact that the reactivity of surface species can dramatically depends on the nature of the feed present, and that purge-type experiments are not suited to determine the true reactivity of adsorbates in the present case, and most likely in many other instances.
While studying the exchange of the surface species during the RWGS isotopic exchange, we also recorded the exchange of the main gas-phase reaction product, i.e. CO. Figure 5 shows the relative intensities of the ${ }^{12} \mathrm{C}$-containing surface species as measured by DRIFTS and the ${ }^{13} \mathrm{CO}$ concentration as measured by mass spectrometry. Using the time needed to half-exchange a species, it can be clearly seen that formates were exchanged on a timescale that was significantly longer than that needed for the exchange of the reaction product, under these circumstances. It can therefore be conclude that formates were mostly spectator species in the present case. On the contrary, carbonyl and carbonate species were exchanged on a timescale that was essentially identical to that of $\mathrm{CO}$, and therefore those compounds are potentially main reaction intermediates.

Formates have often been proposed as a surface intermediate during reaction between $\mathrm{CO}_{2}$ and $\mathrm{H}_{2}$ for the RWGS or methanol synthesis over Pt $[15,25]$ or Cu-based materials [26-27]. However, the conclusions of the only other RWGS study on Pt-CeO ${ }_{2}$ available [15] need to be taken with caution. It appears that the typical purge time of the DRIFTS cell used (which is of the same make as ours) was about 60 -fold slower than ours, i.e. ca. $6 \mathrm{~min}=360 \mathrm{~s}$ (see Fig. 2 of [15]) against $6 \mathrm{~s}$ in our case, while the flowrate used was $50 \%$ higher (i.e. ca. $150 \mathrm{~mL} \mathrm{~min}^{-1}$ against $100 \mathrm{ml} \mathrm{min}^{-1}$ ). A possible explanation was that the high pressure dome used by this other group actually rested directly against the crucible surface, creating a high pressure drop, and the gas feed actually by-passed the catalyst bed. This suggests that the kinetic study carried out there was disguised by transport and the
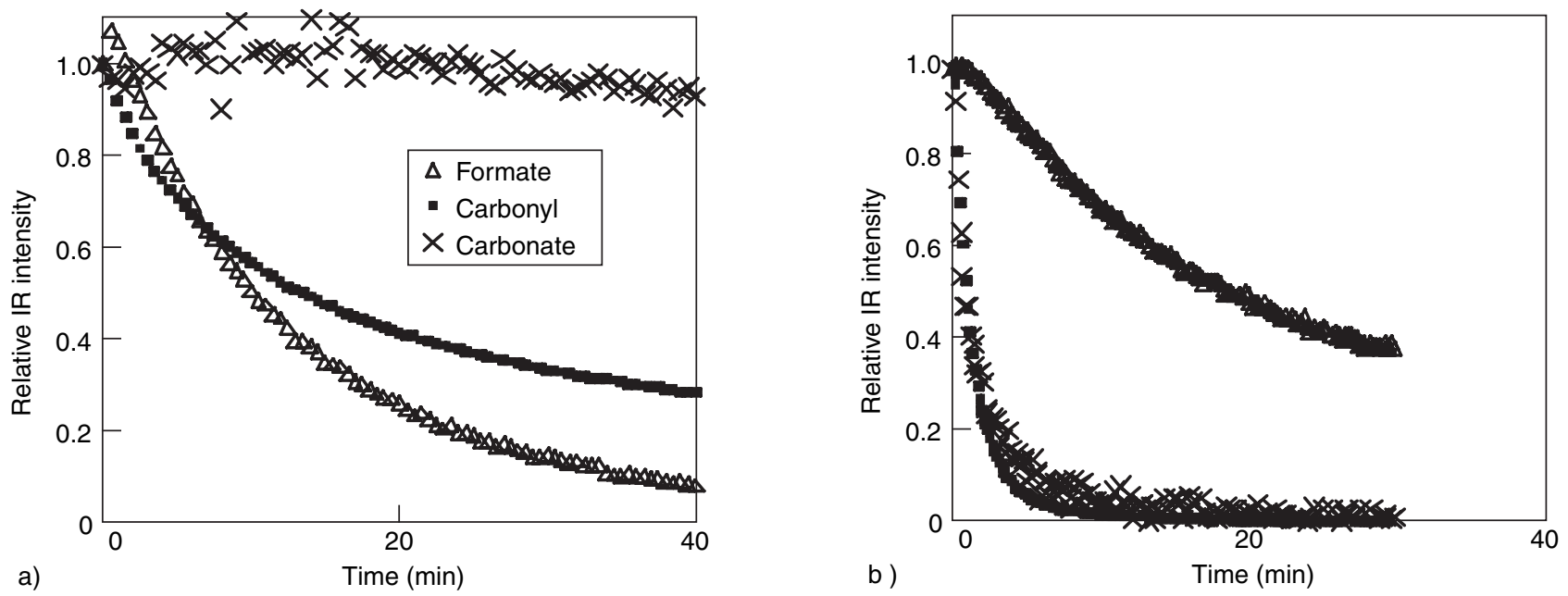

Figure 4

a) Relative intensity of the IR bands of the ${ }^{12} \mathrm{C}$-containing $(\Delta)$ formate, $(\bullet)$ carbonyl and $(\mathrm{x})$ carbonate species as a function of time under Ar, following steady-state state in $1 \%{ }^{12} \mathrm{CO}_{2}+4 \% \mathrm{H}_{2} . \mathrm{T}=498 \mathrm{~K}$.

b) Relative intensity of the IR bands of the ${ }^{12} \mathrm{C}$-containing $(\Delta)$ formate, $(\bullet)$ carbonyl and (x) carbonate species as a function of time under $1 \%$ ${ }^{13} \mathrm{CO}_{2}+4 \% \mathrm{H}_{2}$ in $\mathrm{Ar}$, following steady-state state in $1 \%{ }^{12} \mathrm{CO}_{2}+4 \% \mathrm{H}_{2} . \mathrm{T}=498 \mathrm{~K}$. 
related conclusions cannot be used reliably. As a consequence, our own studies on $\mathrm{Pt}-\mathrm{CeO}_{2}$ are so far the only ones that can reliably be used, showing that formates as seen by IR are not involved in the RWGS under our set of conditions over our catalyst.

It should stressed that the observed exchange of surface and gas-phase species could be partly due, on the one hand, to an adsorption-desorption equilibrium of the reactant $\mathrm{CO}_{2}$, which is an acidic molecule and readily adsorbs onto the basic sites of ceria [28] and, on the other hand, to a similar adsorption-desorption equilibrium of the reaction product $\mathrm{CO}$ (i.e. chromatographic effects). We do not believe that the latter (i.e. reaction product $\mathrm{CO}$ readsorption) induced any significant modification of the true reaction intermediate exchange curve since other experiments (to be reported elsewhere) showed that the transient curve of $\mathrm{CO}$ (measured during a ${ }^{12} \mathrm{CO}$ to ${ }^{13} \mathrm{CO}$ isotopic switch) over the same catalyst was essentially identical to that of the inert tracer. The possibility of chromatographic effect on the reactant, i.e. $\mathrm{CO}_{2}$, is probably greater, and this particular aspect will be developed in forthcoming papers dealing with the forward WGS reaction.

The main outcome of the present data was to indicate that the formates as observed by IR were not the main reaction intermediate of the RWGS over this catalyst under our experimental conditions (i.e. formates could be intermediates in other circumstances such as WGS conditions, under which large concentrations of water prevail [20]). The determination of the true intermediates (e.g. carbonyl and carbonate) would require that any potential chromatographic effect is eliminated and that a proper calibration curves for the quantification of the CO signal is carried out [22].

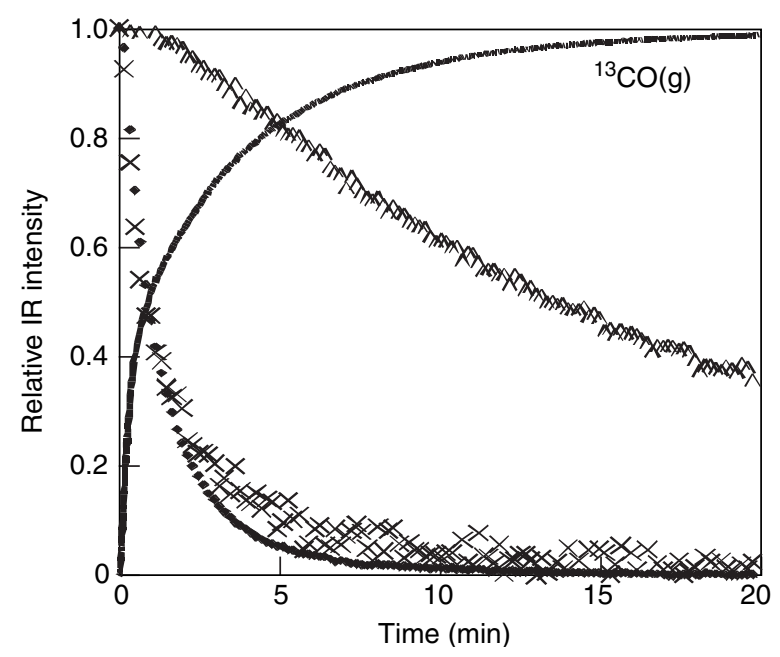

Figure 5

Comparison of the relative rate of exchange of the ${ }^{12} \mathrm{C}$-containing $(\Delta)$ formate, $(\bullet)$ carbonyl and $(\mathrm{x})$ carbonate species and the concentration of ${ }^{13} \mathrm{CO}$ as a function of time under $1 \%$ ${ }^{13} \mathrm{CO}_{2}+4 \% \mathrm{H}_{2}$ in $\mathrm{Ar}$, following steady-state state in $1 \%$ ${ }^{12} \mathrm{CO}_{2}+4 \% \mathrm{H}_{2} . \mathrm{T}=498 \mathrm{~K}$.

\section{CONCLUSIONS}

The reactivity of the surface intermediates formed under reverse water-gas shift conditions over a $\mathrm{Pt}-\mathrm{CeO}_{2}$ were followed under an inert gas (i.e. Ar) and during steady-state conditions using an isotopic technique. Under Ar, the carbonates were essentially stable and less reactive than the formates, whereas under the labelled feed at chemical steadystate conditions, the carbonates were exchanged significantly faster than the formates. The data reported here clearly show the need to use operando or steady-state techniques (such as steady state isotopic kinetic analysis, SSITKA) to determine the reactivity of surface species in actual operating conditions. The simultaneous collection of spectroscopic and kinetic data using a single bed DRIFT reactor is a powerful tool to investigate the reaction mechanism of heterogeneous catalytic reactions, and in particular to evidence spectator species.

\section{REFERENCES}

1 Topsøe, H. (2003) J. Catal., 216, 155.

2 Schilke, T.C., Fisher, I.A., and Bell, A.T. (1999) J. Catal., $\mathbf{1 8 4}, 144$.

3 Weckhuysen, B.M. (2003) Phys. Chem. Chem. Phys., 5, 4351.

4 Bruckner, A. (2003) Catal. Rev. 45, 97.

5 Banares, M.A. (2005) Catal. Today, 100, 71.

6 Lesage, T., Verrier, C., Bazin, P., Saussey, J., Malo, S. Hedouin, C., Blanchard, G. and Daturi, M. (2004) Top. Catal., 30, 31 .

7 Meunier, F.C. and Daturi, M. (2006) Catal. Today, 113, 1.

8 Ueno, A., Onishi, T. and Tamaru, K. (1970) Trans. Farad. Soc. 66, 567756

9 Chuang, S.S.C, Brundage, M.A., Balakos, M.W. and Srinivas, G. (1995) Appl. Spectrosc., 49, 1151.

10 Stockwell, D.M., Chung, J.S. and Bennett, C.O. (1988) J. Catal., 112, 135.

11 Efstathiou, A.M., Chafik, T., Bianchi, D. and Bennett, C.O. (1994) J. Catal., 147, 24.

12 Agnelli, M., Swaan, H.M., Marquez-Alvarez, D. Martin, G.A. and Mirodatos, C. (1998) J. Catal., 175, 117.

13 Chafik, T., Efstathiou, A.M. and Verykios, X.E. (1997) J. Phys. Chem. B, 101, 7968.

14 Goguet, A., Tibiletti, D., Meunier, F.C., Breen, J.P. and Burch, R. (2004) J. Phys. Chem. B, 108, 20240.

15 Jacobs, G. and Davis, B. (2005) Appl. Catal., A-Gen., 284, 31.

16 Shido, T. and Iwasawa, Y. (1992) J. Catal., 136, 493.

17 Li, Y., Fu, Q. and Flytzani-Stephanopoulos, M. (2000) Appl. Catal. B-Environ., 27, 179.

18 Jacobs, G., Williams, L., Graham, U., Sparks, D., and Davis, B.H. (2003) J. Phys. Chem. B, 107, 10398.

19 Jacobs, G., Williams, L., Graham, U., Sparks, D., Thomas, G., Davis, B.H. (2003) Appl. Catal. A-Gen., 252, 107.

20 Jacobs, G., Chenu, E., Patterson, P.M, Williams, L., Sparks, D., Thomas, G. and Davis, B.H. (2004) Appl. Catal. A-Gen., 258, 203 . 
21 Tibiletti, D., Goguet, A., Meunier, F.C., Breen, J.P. and Burch, R. (2004) Chem. Commun., 1636.

22 Tibiletti, D., Goguet, A,. Reid, D., Meunier, F.C. and Burch, R. (2006) Catal. Today, 113, 94.

23 Bernal, S., Botana, F.J., Calvino, J.J., Cauqui, M.A., Jobacho, G.A., Pintado, J.M. and Rodriguez-Izquierdo, J.M. (1993) J. Phys. Chem., 97, 4118.

24 Bazin, P., Saur, O., Lavalley, J.C., Daturi, M. and Blanchard, G. (2005) Phys. Chem. Chem. Phys., 7, 187.
25 Jacobs, G. and Davis, B. (2005) Appl. Catal. A-Gen., 285, 43.

26 Chena, C.S., Cheng, W.H. and Lin, S.S. (2003) App. Catal. A-Gen., 238, 55.

27 Jung, K.D. and Bell, A.T. (2000) J. Catal., 193, 207.

28 Meunier, F.C., Tibiletti, D., Goguet, A., Reid, D. and Burch, R. (2005) Appl. Catal. A-Gen., 289, 104.

Final manuscript received in August 2006 work owned by others than IFP must be honored. Abstracting with credit is permitted. To copy otherwise, to republish, to post on servers, or to redistribute to lists, requires prior specific permission and/or a fee: Request permission from Documentation, Institut français du pétrole, fax. +33147527078 , or revueogst@ifp.fr. 